\title{
PROPAGANDA DAESH
}

Znakiem firmowym Daesh ${ }^{1}$ jest krwawa propaganda. Można zaryzykować tezę, że zanim w Europie uaktywnili się inspirowani przez Daesh zamachowcy, to w percepcji Europejczyków właśnie propaganda była najbardziej rozpoznawalnym elementem związanym z aktywnością tej organizacji. Tym samym zasadnym staje się pytanie o funkcje, jakie w zamyśle twórców samozwańczego ,kalifatu” mająpełnić ich filmowe produkcje. Przyjęto założenie, zgodne z przedstawioną w ramach NATO STRATCOM publikacją Daesh Information Campaign and its Influence, zgodnie z którym propagandę Daesh można podzielić na trzy typy narracji: polityczną, religijną i społeczną (Zgryziewicz, 2015: 29-32). W celu weryfikacji tej hipotezy podzielono niniejszy artykuł na trzy części. W pierwszej scharakteryzowano Daesh jako organizację terrorystyczną dążącą do własnej państwowości. W części drugiej skoncentrowano się na kluczowych założeniach propagandy Daesh, zaś część ostatnia zawiera analizę wybranych przekazów propagandowych. Konkluzje - z racji niemożności dotarcia do całości przekazu propagandowego Daesh i wynikającego z tego skupienia się na wybranych przekazach - są efektem wnioskowania indukcyjnego. Ograniczenia związane z materiałem badawczym wynikają nie tylko z dostępności. Badane produkcje filmowe zostały zawężone do tych, które są oficjalnymi przekazami, sygnowanymi przez medialne oddziały poszczególnych produkcji ${ }^{2}$.

\section{DAESH - DĄŻENIE DO WEASNEJ PAŃSTWOWOŚCI}

Organizacja terrorystyczna, której propaganda stanowi główny przedmiot zainteresowania niniejszego artykułu, rości sobie prawo do bycia pełnoprawnym, państwowym uczestnikiem stosunków międzynarodowych. Tym samym zasadnym staje się scharakteryzowanie jej w oparciu o kryteria bazujące na postanowieniach Konwencji o prawach $i$ obowiqzkach państw, przyjętej w Montevideo w 1933 r., tj. ludności, władzy i terytorium.

1 Organizacja ta sama siebie nazywa Państwem Islamskim. Powstała na bazie Państwa Islamskiego w Iraku i w Lewancie/Syrii (ISIL/ISIS). Określenie Daesh pochodzi od arabskojęzycznej wersji tej ostatniej nazwy (ad-dawla al-islāmiyya fì al- 'irâq wa ash-shām) i ma na celu podkreślenie, że wbrew intencjom terrorystów ich organizacja nie jest państwem.

2 O oficjalnym charakterze produkcji świadczy nie tylko tytul (zawierający odniesienia do oddziału odpowiedzialnego za produkcje), ale również sposób montażu - np. flaga Daesh w górnym rogu, śpiewane wersy Koranu w ujęciach pokazujących walki i egzekucje. 
Ludność na terenach opanowanych przez Daesh składa się z dwóch grup. Pierwsza z nich to mieszkańcy danych obszarów. W medialnym dyskursie dominuje przekaz, zgodnie z którym są oni, z powodów religijnych, etnicznych i politycznych, narażeni na represje i zagładę (chrześcijanie, szyici, jazydzi, Kurdowie). Jednakże na większości opanowanych terenów częstokroć dominują sunnici, dla których Daesh niejednokrotnie był i jest nadzieją na lepszą przyszłość. Przykładem jest Mosul - jedno z najważniejszych miast na terytoriach Daesh w większości składa się z sunnitów, którzy mając dość rządów szyitów z Bagdadu, z radością powitali narodziny nowego „kalifatu”. Druga grupa składa się z zagranicznych ochotników. Docierają oni na terytoria Daesh z całego świata i czują się pełnoprawnymi obywatelami „kalifatu”. Ich determinacja prowadzi do niejednoznacznej sytuacji w świetle prawa międzynarodowego, przy założeniu, że pod pojęciem narodu rozumiemy wspólnotę polityczną. Można w tym przypadku rozważać, czy określenie ,naród” nie jest całkowicie chybione względem połączonych polityczną wizją ochotników, chcących walczyć za wspólny polityczny cel, jakim jest powstanie ,kalifatu”. Przyjęcie takiej perspektywy może mieć swoje konsekwencje w świetle prawa narodów do samostanowienia.

Władza w obrębie Daesh jest w niemałym stopniu ukryta, zarówno w zakresie struktury, jak i osób sprawujących poszczególne funkcje. Są oczywiście podejmowane próby rekonstruowania struktury władzy. Miałaby się ona składać z kalifa, siedmioosobowego rządu i gubernatorów prowincji. Niezależnie od rzeczywistej struktury, można przyjąć założenie, że hierarchiczna, niedemokratyczna struktura z ,kalifem” Abu Bakr al-Baghdadim na czele, wypełnia stawiany przed władzą cel - jest skuteczna. Daesh udało się nie tylko opanować i utrzymać spore terytorium, ale również wprowadzić efektywną władzę. Podatki są egzekwowane, szkoły i szpitale działają, organa odpowiedzialne za bezpieczeństwo, tak wewnętrzne, jak i zewnętrzne również sprawują swoją funkcję. Tym samym, ,państwo" islamistów działa sprawnie, nie tylko nie doprowadziło do powstania anarchii, ale wręcz w wielu obszarach aktywności wykazuje się większą skutecznością w realizowaniu państwowych funkcji niż np. szyicki rząd z Bagdadu. Ponadto organizacja działa w przeświadczeniu, że wszellkie podejmowane przez nich działania są wyrazem suwerennej woli, wynikającej z religijnego nakazu odbudowy „kalifatu”. Dla Daesh fakt posiadania suwerenności potwierdzają licznie przybywający ochotnicy i życzliwość wielu mieszkańców opanowanych terenów. Jednocześnie źródeł suwerenności upatrują w Islamie i wynikającym z niego - w ich interpretacji - obowiązku odbudowy „kalifatu”, będącego domem dla wszystkich sunnitów.

Terytorium opanowane przez organizację rodzi wyzwania trojakiego typu. Po pierwsze, są to tereny podlegające ciągłym atakom, zarówno ze strony Syrii i Iraku (z których to ziem składa się terytorium Daesh), jak i ze strony międzynarodowej koalicji. Po drugie, jest to terytorium niespójne - opanowane zostały miasta i miasteczka, obszary pomiędzy nimi często są ziemią niczyją. Jednakże mimo tych zagrożeń, przynależność poszczególnych miast do Daesh ma charakter względnie trwały. Zarówno Syria, jak i Irak nie mają wystarczającego potencjału do odbicia swoich ziem. Jednocześnie międzynarodowa koalicja ogranicza swoje zaangażowanie do nalotów i działalności sił specjalnych oraz instruktorów - to oczywiście przynosi organizacji straty, ale jest niewystarczające do opanowania terytorium. Po trzecie, dochodzi do tego istotny problem prawny - zajęte terytoria zostały zagarnięte przy użyciu siły, z pogwałce- 
niem integralności terytorialnej innych państw, co czyni fakt posiadania terytorium niemożliwym do zaakceptowania w perspektywie prawa międzynarodowego.

Choć wskazana na wstępie Konwencja o prawach i obowiqzkach państw określa trzy czynniki warunkujące państwowość, to należy zwrócić uwagę również na kwestię uznania, rozumianego jako konsekwencja zdolności do wchodzenia w relacje z innymi państwami (Konwencja, 1933: Art. 1.d). Zdolność ta jest w doktrynie prawa wiązana (jako jeden z elementów) z uznaniem (Góralczyk, Sawicki, 2015: 141). Istnieje również pogląd, zgodnie z którym uznanie jest warunkiem koniecznym, aby w pełni istniała zdolność do wchodzenia w relacje z innymi państwami (Państwo, 2015: 32). Uznanie przez społeczność międzynarodową Daesh jako państwa jest w chwili obecnej mało prawdopodobne, tak w wymiarze de iure, jak i de facto. Nie można jednak pominąć faktu, że Daesh pewne kontakty z innymi państwami posiada. Dotyczy to przede wszystkim Turcji, która prowadzi mocno niejednoznaczną politykę. Oficjalnie celem prowadzonej przez Turcję akcji antyterrorystycznej są islamscy terroryści i Kurdowie. W praktyce to ta druga grupa stanowi priorytetowy cel, podczas gdy relacje z Daesh niejednokrotnie noszą znamiona cichej współpracy, zarówno w wymiarze militarnym (atakowanie wspólnego wroga, Kurdów), jak i w wymiarze ekonomicznym (handel ropa) ${ }^{3}$. Nie prowadzi to rzecz jasna do uznania, niemniej otwartym pozostaje pytanie, czy z punktu widzenia interesów geopolitycznych trwałe istnienie „kalifatu” byłoby akceptowalnym dla takich państw jak Turcja czy Arabia Saudyjska. Dotychczasowa polityka tych państw sprawia, że takiego wariantu nie można w całości odrzucić (Klein, Kozera, 2015b).

Tym samym na mapie świata pojawiła się organizacja terytorialna, która „ustaliła wyraźną granicę władzy, systemy podatkowy i edukacji oraz wyrafinowanych operacji propagandowych" (Walt, 2015: 42). Podkreśla się przy tym skuteczność terrorystów w walce oraz w egzekwowaniu władzy na opanowanych terytoriach, a także w działaniach wywiadowczych i propagandowych (Weiss, Hassan, 2015: 16). „Tak więc organizacja powszechnie uznana za terrorystyczną coraz skuteczniej buduje na Bliskim Wschodzie suwerenne państwo i de facto jest dziś w stanie nie tylko je kontrolować, ale także go bronić oraz dokonywać dalszej ekspansji" (Cockburn, 2015: 22). Podkreśla się przy tym, że o trwałości może świadczyć nie tylko skuteczność w działaniu, ale i to, że odrodzenie ,kalifatu” jest spełnieniem wielowiekowego arabskiego marzenia (Hanne, Flichy de La Neuville, 2015: 155-156).

\section{PROPAGANDA DAESH - KLUCZOWE ZALOŻENIA}

Według prowadzonych w ramach NATO STRATCOM badań propaganda Daesh dzieli się na trzy obszary tematyczne ${ }^{4}$.

3 Obok Turcji drugim kierunkiem nielegalnej i bardzo dochodowej sprzedaży ropy jest Jordania. Pojawiają się wręcz określenia, że „sprawa ropy to klucz do konfliktu” (Hanne, Flichy de La Neuville, 2015: 106). Co warte podkreślenia, handel taki prowadzą z Turcją również iraccy Kurdowie, czego w rozmowach z Autorem w północnym Iraku w marcu 2015 roku nie ukrywali. Są i takie założenia, zgodnie z którymi Daesh sprzedaje ropę do Turcji właśnie przez kurdyjskich pośredników (Chudziak, 2016).

4 Dane dotyczą treści pojawiających się w najważniejszym czasopiśmie Daesh, „Dabiq”, w okresie lipiec 2014-sierpień 2015. 
Pierwszy obszar ma wymiar polityczny. Samozwańczy „kalif” Baghdadi jest przedstawiany jako nastepca i wysłannik Mahometa. Celem tych przekazów jest zdobycie zaufania w oczach muzułmanów, mają postrzegać „kalifat” jako swój nowy dom, w którym mogą żyć w pokoju. Jest to dom dobrze zorganizowany (pokazuje się efektywność w administrowaniu ,kalifatem”) i bezpieczny (sprawne siły bezpieczeństwa). W celu uwiarygodnienia eksponowane są takie elementy podkreślające państwowość, jak flagi, emblematy i, przede wszystkim, nazwa „Państwo Islamskie”. Przekazy o politycznym charakterze mają stanowić $48 \%$ w propagandzie Daesh.

Druga grupa przekazów, stanowiąca 38\%, to treści religijne. Podkreśla się w nich religijne obowiązki muzułmanów, w tym obowiązek dżihadu. Islam nie jest traktowany jako religia pokoju - on ma nadejść dopiero po pokonaniu wszystkich wrogów. Nim to nastapi, obowiązkiem muzułmanów jest walka. Wśród treści obecnych w przekazie religijnym są i takie, które są adresowane do kobiet, zachęcają do dołączenia się do Daesh i wybrania drogi dżihadu.

Część trzecia, zajmująca 14\%, to treści społeczne. Przeznaczona jest m.in. dla tych, którzy żyjąc w społeczeństwach zachodnich, czują się zagubieni i pozbawieni perspektyw, tak osobistych, jak i zawodowych. Po dołączeniu do Daesh mogą, zgodnie z prezentowanymi treściami, wieść szczęśliwe życie i pełnić rolę w czymś ważnym.

Ponadto przekazy propagandowe powinny pomagać w realizowaniu czterech podstawowych zadań: zdobywania wsparcia (osobowego i finansowego), w zjednoczeniu sunnitów, w zastraszeniu wrogów (co np. odegrało znaczącą rolę przy zajmowaniu Mosulu), oraz w informowaniu o efektywności organizacji. Należy przy tym podkreślić, że organizacja umiejętnie dobiera treści i narzędzia w sposobie przekazu, w zależności od grupy docelowej i związanych z nią oczekiwań. Nie każdy odbiorca wiadomości jest gotowy do otrzymywania wiadomości każdego typu, jednakże każdy potencjalny rekrut czy donator jest ważny, natomiast radykalizacja może przyjść z czasem (Zgryziewicz, 2015: 29-37).

Nie jest to jedyny możliwy podział typów narracji i celów. Można się również spotkać z podziałem narracji na sześć obszarów:

1) brutalność - przekazy, w których dominuje przemoc, są przeznaczone dla różnych odbiorców. Niektóre są tworzone na użytek ,wewnętrzny”, tak aby zastraszyć wrogów, którzy są na terenach już opanowanych i takich, które terroryści zamierzają opanować (wpisują się w to np. egzekucje żołnierzy Bashara al-Assada). Inne - takie jak egzekucje zagranicznych dziennikarzy - przeznaczone są dla międzynarodowego audytorium:

2) miłosierdzie - Daesh pokazuje, że potrafỉ wybaczać swoim przeciwnikom. O ile przyją prosić o przebaczenie, nim zostaną odnalezieni, bowiem wówczas na miłosierdzie już nie mogą liczyć. Tym samym przekazom zawierającym miłosierdzie, towarzyszą te związane z brutalnością, w celu pokazania, czym kończy się niewystapienie o przebaczenie;

3) skierowana do ofiar - również i tym przekazom towarzyszy brutalność. Są to treści skierowane do tych, którzy odczuwają potrzebę sprawiedliwości, wyrównania krzywd. Przykładem może być egzekucja (spalenie żywcem) jordańskiego pilota - towarzyszyły jej obrazy ofiar (w tym dzieci), będących jakoby skutkiem nalotów wymierzonych w Daesh. Podobna konstrukcja (zderzenie egzekucji ze zdjęciem 
dziecka-ofiary) wystąpiła przy egzekucji oskarżonych o szpiegostwo (część wysadzono w powietrze - m.in. przy użyciu RPG, część utopiono, zamknąwszy uprzednio „szpiegów” w metalowej klatce);

4) wojna - przekazy pokazujące relacje z walk, „reportaże wojenne”, zdjęcia z parad z wykorzystaniem ciężkiego sprzętu czy też z obozów szkoleniowych, składają się na narrację wojenna, która jest nierozerwalnie związana $\mathrm{z}$ powszechną percepcją Daesh. Pokazywanie wojennej efektywności ma na celu podnoszenie morale oraz stworzenie atrakcyjnego wizerunku dla potencjalnych rekrutów;

5) przynależność - te treści adresowane są głównie do potencjalnych rekrutów. Pokazują Daesh jako organizację zapewniającą bezpieczeństwo. Pojawiają się więc idylliczne zdjęcia (wspólne picie herbaty, śpiewy), mające pokazywać przyjaźń i spokój pomiędzy członkami Daesh. Jednocześnie jest to przekaz demokratyczny, nastawiony do każdego, czym odróżnia się od akcentowanej przez Al-Kaidę elitarności;

6) utopia - pokazanie, że marzenie pokoleń o odrodzeniu 'kalifatu' właśnie się ziszcza, ponieważ Daesh nie tylko o tym mówi, ale wprowadza tę utopijną wizję w życie.

Powyższe narracje są adresowane do różnych grup odbiorców, takich jak: przeciwnicy (aktualni i potencjalni) - celem jest zastraszenie; aktywni członkowie, potencjalni rekruci i propagatorzy (Winter, 2015: 22-36).

Centralną platformą wykorzystywaną przez Daesh do propagowania swoich przekazów jest Twitter - stanowi on swoisty agregat treści pojawiających się w sieci (Zgryziewicz, 2015: 39). Medium to jest wykorzystywane przez licznych propagandystów i zwolenników Daesh - jak tylko pojawi się jakiś nowy materiał propagandowy, natychmiast jest on rozpowszechniany za pomocą Twittera. Tym samym Daesh wykorzystuje nowoczesne technologie oferowane przez zglobalizowany świat lepiej niż ktokolwiek inny w świecie islamu (Melhem, 2015: 152). W zakresie wojny o umysły ,żadna sunnicka organizacja islamistyczna nigdy nie osiagnęła swoja działalnością tak wiele, co obecnie IS. I nie chodzi tu tylko i wyłącznie o samą taktykę działań czy ich brutalność. Wszak bojownicy Al-Kaidy Półwyspu Arabskiego (AQAP), krzyżujący publicznie swoich wrogów w Jemenie, czy nigeryjskiego Boko Haram, gwałcący masowo setki nieletnich uczennic uprowadzonych z katolickich szkół - w niczym nie ustępują mordercom z kalifatu. Ci ostatni potrafią jednak swoją brutalność niezwykle skutecznie „sprzedać” medialnie, czym zyskują dodatkowy efekt psychologiczny, znacznie poszerzający pole rażenia ich aktywności" (Otłowski, 2016: 19).

Ten dodatkowy efekt psychologiczny został uzyskany m.in. podczas zajmowania Mosulu. Na dwa tygodnie przed rozpoczęciem operacji wyemitowano film propagandowy pt. Szczęk mieczy, zawierający wiele przykładów brutalności Daesh (obcinanie głów, jeńcy sami kopiący sobie groby) i skuteczności w identyfikowaniu przeciwnika (m.in. namierzanie wrogów dzięki przebieraniu się w mundury irackich sił bezpieczeństwa). W efekcie szyici byli przerażeni, a sunnici zaczęli poważnie rozważać złożenie przysięgi wierności w celu uniknięcia egzekucji (Weiss, Hassan, 2015: 269-272). Nie dziwi zatem powszechna opinia wśród irackich Kurdów, że nie ma powodu, aby umierali za Mosul, skoro jego mieszkańcy swoich nowych panów wybrali sobie sami (Klein, Kozera, 2015a). 


\section{ANALIZA WYBRANYCH PRZEKAZÓW PROPAGANDOWYCH}

Taki wybór, jak ten dokonany przez mieszkańców Mosulu, był dosyć powszechny w miastach, w których przeważali sunnici. Już w pierwszych minutach Szczęku mieczy widać nie tylko próbę zamanifestowania potęgi Daesh (pokaz sprzętu, ujęcia z walk), ale również ludzi, wychodzących na ulice, by z najbliższej odległości oglądać i filmować wiwatujących członków Daesh. Towarzyszą temu wszechobecne flagi organizacji, całość pierwszych minut utrzymana jest w nastroju podniosłym, widać również radość, tak, jakby nastało państwo oczekiwane przez ludzi. Pojawienie się nowego państwa potwierdza, poprzedzone przemową, niszczenie paszportów przez członków Daesh. Po pierwszych niespełna pięciu minutach następuje pokaz brutalności i skuteczności Daesh. Kolejne ujęcia pokazują 'polowania' urządzane na auta, przewożące ubranych w cywilne ubrania żołnierzy. Wszystko utrzymane jest w duchu ,wymierzania sprawiedliwości" - do jednej z ofiar strzelano w terenie zabudowanym, przy jadących z przeciwległej strony (tej, po której poruszała się ofiara) samochodach. Strzały oddano tak, aby nie dosiegły ani przypadkowych samochodów, ani towarzyszącego ofierze mężczyzny.

Kolejne ujęcia przedstawiają mężczyzn, którzy przyszli złożyć przysięgę wierności - po tym akcie, każdy z nich, z uśmiechem na twarzy, wita się z zamaskowanymi członkami Daesh. Następnie pojawiają się trwające ponad dziesięć minut ujęcia z walk, widać m.in. jeńców rozstrzeliwanych na miejscu i fortyfikacje irackiej armii niszczone po zdobyciu (co ma symbolizować nastanie nowego porządku na zajętych obszarach). Taka sekwencja zostaje w godzinnej produkcji powtórzona wielokrotnie - po scenach walk pojawiają się kolejne ujęcia, wpisujące się w typowo polityczną narrację - nauczania, niszczenia paszportów, przebaczania tym, którzy przyszli wyznać swoje winy, uśmiechniętych ludzi, dzieci wznoszących palec wskazujący itp. Wśród relacji wojennych są m.in. ujęcia z „polowań” na członków irackiego wojska - są zatrzymywani przy fikcyjnej blokadzie drogowej, a także we własnych domach. Egzekucjom (niektórzy sami muszą sobie wykopać grób) towarzyszy wyjaśnienie lektora, dlaczego dana osoba została zabita.

Dla uwiarygodnienia pokazywane są zdjęcia ofiar w mundurach irackiego wojska. Sposób przeprowadzania egzekucji może wskazywać na pewną ewolucję w zakresie wybieranych metod. Dopiero pod koniec filmu pojawia się, tak popularne w kolejnych produkcjach, odcięcie głowy.

Wkrótce po tym filmie pojawiła się jedna z najkrwawszych produkcji propagandowych Daesh $\left(\mathrm{New}^{5}, 2014\right)$. Trzydziestosześciominutowy film powstał po zdobyciu Tiktiru, rodzinnego miasta Saddama Husajna. Przez pół godziny film ma zbliżoną konstrukcję do poprzedniego. Przeplatają się ujęcia wojenne (same walki, niszczenie umocnień, „polowania” na drodze) z wątkami religijno-państwowymi (nauczanie, składanie przysięgi połączone z manifestacją radości). Jedynymi wyróżnikami - w stosunku do poprzedniej produkcji - są wypowiedzi Abu Bakr al-Baghdadiego, niszcze-

Niestety, nie udalo się ustalić dokładnej nazwy tej produkcji, przytoczona w publikacji jest taka, pod jaką film figuruje na portalu www.liveleak.com - prawidłowość ta dotyczy wszystkich materialów z tego portalu. 
nie obiektów szyickich (w tym wysadzanie meczetów) i skala manifestacji ( $\mathrm{z}$ użyciem wojskowego ciężkiego sprzętu oraz z thumami cywili). Masakra, za sprawą której ta produkcja stała się znana, zajmuje ostatnie niespełna pięć minut. Widać podczas nich irackich jeńców dowożonych na miejsce zbrodni, błagających o litość, a następnie masowo mordowanych. Miejsca kaźni są różnorodne, m.in. nad rzeką (gdzie po strzale w tył głowy ciała od razu wrzucano do wody). W jednej ze scen jeńcy zabijani są na placu - liczna grupa siedzi, a egzekutor strzela do nich, sprawiając wrażenie, że robi to od niechcenia. Film kończy widok członka Daesh niespiesznie spacerującego z wielką flagą terrorystów na tle miasta. Całość składa się w jeden, spójny przekaz, mówiący o nastaniu nowego „kalifatu”. Tuż po opublikowaniu relacji z masakry liczbę ofiar oszacowano na przynajmniej pół tysiąca, sami terroryści poinformowali, że w Tikricie zabili tysiąc siedmiuset jeńców (Iraq, 2014).

Szerokim echem odbiła się w światowych mediach także egzekucja jordańskiego pilota. Nie było to, dla propagandystów Daesh, zwykłe wydarzenie. Zorganizowali wokół tego prawdziwy, medialny spektakl. Przed zabiciem pilota wyemitowali niespełna pięciominutowy film Wywiady na temat jordańskiego pilota. Pytali się w nim zwykłych muzułmanów o to, jaki powinien być jego los. Po egzekucji zostały wyemitowane dwa krótkie filmiki, ukazujące reakcje muzułmanów - Spojrzenie muzułmanów na spalenie jordańskiego pilota oraz Radość muzulmanów z odplaty na jordańskim pilocie. Szczególne wrażenie robi ten drugi, pokazuje $m$.in. publiczne oglądanie nagrania z egzekucji. W pierwszych rzędach stoją mali chłopcy, którzy później, z co najmniej porównywalnym jak $\mathbf{u}$ dorosłych entuzjazmem, komentują egzekucję. Jej zapis jest następnie rozdawany przez członka Daesh na płytach CD.

Sama egzekucja jest częścią ponad dwudziestominutowej produkcji pt. Uzdrowienie serc wierzacych, która zaczyna się ukazaniem Jordanii jako wroga Daesh. Składaja się na to ujęcia króla jordańskiego spotykającego się z prezydentem USA, Sekretarzem generalnym NATO, a także zdjęcia wskazujące na współpracę żołnierzy jordańskich z amerykańskimi. Następnie przedstawiono urywki relacji ze światowych mediów, dotyczące zestrzelenia i pojmania pilota. Wreszcie pojawia się on sam, jego trwającym blisko dziesięć minut wyznaniom towarzyszą kadry mające pokazać skuteczność sił bezpieczeństwa Daesh, m.in. jego zdjęcie w mundurze i podstawowe dane. Pilot podaje m.in. informacje dotyczące nalotu i koalicji (państwa, rodzaje samolotów, rodzaj uzbrojenia, lotniska, z których są dokonywane naloty), jest to wzbogacone odpowiednimi, dobrze i dynamicznie zmontowanymi grafikami i zdjęciami. Po zakończeniu części z wypowiedzią pilota pojawiają się przemieszane ze sobą ujęcia, pokazujące naloty (często z perspektywy „krzyżowców”) i ich ofiary, najczęściej dzieci. Podobny kolaż zastosowano, pokazując pilota idącego na miejsce kaźni - towarzyszą temu kadry ofiar nalotów i akcji ratunkowych. Ujęcia te wyraźnie pokazują, że pilot jest winny i powinien ponieść sprawiedliwą karę. Moment egzekucji poprzedzony jest odpowiednio dozowanym napięciem, ujęcia pokazują pilota w klatce pośród jednolicie umundurowanych i uzbrojonych członków Daesh, towarzyszy temu całkowita cisza. Po tym następuje przyspieszenie, pojawia się śpiew (wersy Koranu). Ujęcia pokazujące płonącego pilota zajmują minutę. Na koniec pojawia się ogłoszenie o wynoszącej sto złotych dinarów nagrodzie dla każdego, kto zabije krzyżowca-pilota oraz zdjęcia i dane dziesięciu pilotów (biorących zdaniem Daesh udział w nalotach) z adnotacją że są poszukiwani martwi. 
Produkcje propagandowe pokazują skuteczność organizacji i gotowość poradzenia sobie z każdym wrogiem również za sprawą filmów pokazujących szkolenia. W jednym z nich (ISIS Training in, 2015) widać wyraźną stylizację bazującą na produkcjach zachodnich, właściwych dla sił specjalnych i oddziałów szturmowych. Jest zatem dużo dynamizmu, pokonywania przeszkód, opuszczania się na linie i symulowanych szturmów na budynki. Są również produkcje pokazujące szkolenia dzieci (ISIS Training Children, 2015) - np. nieco ponad dwuminutowa produkcja pokazuje szkolenie zarówno ideologiczno-religijne, jak i typowo wojskowe, zawierające szkolenie fizyczne i związane z posługiwaniem się bronią, działaniami w grupie, symulowanymi szturmami. Nie brakuje również symulowanych egzekucji. Postawy około dziesięcioletnich chłopców świadczą o ogromnym fanatyzmie.

Jak już wspomniano, w propagandzie Daesh nie brakuje również i takich produkcji, które są skierowane do ofiar. Niespełna pięciominutowy film pt. Bombardowanie zwykbych muzutmanów przez krzyżowców przedstawia ofiary przeprowadzonego przez koalicję ataku na wioskę w okolicach Kobane. Jest ich ponad sto, są to głównie kobiety i dzieci. Kolejne ujęcia pokazują zabite dzieci i rozpaczających oraz wyrażających swój gniew mężczyzn, są również ujęcia ze szpitala i z przygotowań do pogrzebu. W podobnej produkcji, krzyżowcy bombardują niewinnych muzułmanów w okolicach Aden, wśród ofiar są głównie dorośli. Pokazana została również pomoc, jaka została im udzielona - zarówno medyczna, jak i finansowa. Przedstawiciel Daesh chodził od domu do domu, wręczając mieszkańcom koperty zawierające pieniądze.

Jeszcze ciekawszą produkcją, z obszaru tych, w których muzułmanie są przedstawiani jako ofiary, jest film pt. Stabilność muzulmanów mimo bombardowań krzyżowców. Przedstawia ona zniszczenia b?d?ce efektem nalotów koalicji (sama koalicja też została przedstawiona pod postacią kilkudziesięciu flag, jest wśród nich flaga Polski). Pokazany jest również proces odbudowy. Interesującym zabiegiem jest wykorzystanie ujęć z bombardowań dokonanych przez lotnictwo koalicji. Zachowano przy tym oryginalną pisownię, m.in. określenie Daesh, które jest przez terrorystów uznawane za obraźliwe. Składa się to na jasny przekaz - niezależnie od bombardowań i od tego, jak zachód się nimi chwali, życie na terenach opanowanych przez Daesh toczy się normalnie, ludzie chodzą na zakupy, a bazar ${ }^{6}$ pełen jest towarów i kupujących.

Są produkcje, w których przemoc nie występuje, pokazane jest za to budowanie wspólnoty. Np. w siedemnastominutowej produkcji pt. Z ciemności do światta zaprezentowane zostały modlitwy, nauczanie i wspólne posiłki. Pojawiają się również produkcje skupiające się na dobroczynnej działalności członków Daesh. W jednej z nich (Islamic, 2016) pokazana jest nie tylko wszechstronna pomoc (pieniądze, talony, żywność), ale również to, że członkowie Daesh potrafią dotrzeć do każdego potrzebującego, nawet na największym pustkowiu. Pomoc sprawia wrażenie sformalizowanej (co może nadawać jej ,państwowego" charakteru). Talony są starannie wypisywane, jeden $z$ obdarowanych potwierdza odbiór darów odciskiem kciuka.

Szczególne znaczenie ma produkcja zderzająca świat zachodu z „kalifatem” (No respite, 2015). Ten pierwszy, pod przewodnictwem USA, przedstawiony jest jako nasta-

${ }^{6}$ Bazaar to typowe określenie umieszczonego w centralnym punkcie arabskich miast murowanego, dużego i wysokiego targu. 
wiony na konfrontacje, wydający ogromne środki na prowadzenie wojen i nie potrafiący zapewnić swoim obywatelom szczęścia i bezpieczeństwa. Nastawienie na konfrontacje oznaczać ma wojnę przeciw Islamowi i muzułmanom, prowadzoną przez koalicję sześćdziesięciu państw (w tym przez Polskę). Dla odmiany „kalifat”, mający mieć obszar większy od Wielkiej Brytanii, to miejsce bezpieczne i pełne szczęśliwych ludzi. Podstawą tego jest zjednoczenie w oparciu o Islam i szariat.

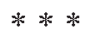

Analiza wybranych produkcji propagandowych potwierdziła różnorodność przekazu Daesh. Na bazie przeanalizowanych produkcji można dokonać uogólnienia, wskazującego na dwojaki typ produkcji propagandowych. Pierwszy z nich to filmy krótkie, kilkuminutowe - są one zazwyczaj dedykowane jednemu celowi, np. budowaniu wspólnoty czy zaspokajaniu potrzeby sprawiedliwości (np. przez pokazanie ofiar „krzyżowców” i wymierzonej im kary). Drugi typ to produkcje długie, w których pojawiają się różne typy przekazów, są one starannie przemieszane, pokazując wątki polityczne (budowanie państwa), religijne (dżihad) i społeczne (budowanie wspólnoty). Całość sprawia wrażenie przemyślanej i dobrze dopracowanej, wpisującej się w nadrzędny cel, jakim jest przekonanie świata, że na geopolitycznej mapie pojawił się nowy podmiot, który jest trwały, ma solidne fundamenty i jest zdolny się obronić, niezależnie od tego, jak bardzo „krzyżowcy” będą go zwalczać. Tym samym sunnici doczekali się wreszcie upragnionego „kalifatu”, zdolnego zapewnić im bezpieczeństwo.

\section{BIBLIOGRAFIA}

Bombing of the Crusaders Upon the Ordinary Muslims - Wilāyat Halab (2015), http://jihadology.net/2015/05/03/new-video-message-from-the-islamic-state-bombing-of-the-crusadersupon-the-ordinary-muslims-wilayat- $\% \mathrm{E} 1 \% \mathrm{~B} 8 \% \mathrm{~A} 5 \mathrm{alab} /(12.04 .2016)$.

Chudziak M. (2016), Wróg moich wrogów - Turcja wobec Państwa Islamskiego, http://www.osw.waw.pl/ pl/publikacje/komentarze-osw/2016-02-24/wrog-moich-wrogow-turcja-wobec-panstwa-islamskiego (12.04.2016).

Clanging of the Swords, Part 4 (2014), http:/jihadology.net/2014/05/17/al-furqan-media-presentsa-new-video-message-from-the-islamic-state-of-iraq-and-al-sham-clanging-of-the-swords-part-4/ (12.04.2016).

Cockburn P. (2015), Państwo Islamskie, Warszawa.

Crusaders Bombing of the Innocent Muslims in the Aden Neighborhood-Wilāyat Ninnawā (2015), http://jihadology.net/2015/05/27/new-video-message-from-the-islamic-state-crusaders-bombing-of-the-innocent-muslims-in-the-aden-neighborhood-wilayat-ninawa/ (12.04.2016).

From the Darkness to the Light - Wilayyat al-Khayr (2015), http:/jihadology.net/2015/04/16/ new-video-message-from-the-islamic-state-from-the-darkness-to-the-light-wilayat-al-khayr/ (12.04.2016)

Góralczyk W., Sawicki S. (2015), Prawo międzynarodowe publiczne w zarysie, Warszawa.

Hanne O., Flichy de La Neuville (2015), Państwo Islamskie. Geneza nowego kallfatu, Warszawa. 
Healing the believers' chests (2015), http://video.foxnews.com/v/4030583977001/warning-extremely-graphic-video-isis-burns-hostage-alive/?\#sp=show-clips (12.04.2016).

Interviews About the Jordanian Pilot - Wilāyat al-Raqqah (2015), http://jihadology.net/2015/01/16/ new-video-message-from-the-islamic-state-interviews-about-the-jordanian-pilot-wilayat-alraqqah/ (12.04.2016).

Iraq: Islamic State Executions in Tikrit (2014), https://www.hrw.org/news/2014/09/02/iraq-islamic-state-executions-tikrit (12.04.2016).

ISIS training in Ninawa (2015), http://www.liveleak.com/view?i=863_1426436099 (12.04.2016)

ISIS Training Children To Be Killers (2015), http://www.liveleak.com/view?i=0fc_1449181522 (12.04.2016).

Islamic State Distribute Money, Food and Wheel Chair to the Poor (2016), http://www.liveleak.com/view?i=5ad 1456853020 (12.04.2016).

Joy of the Muslims With the Retribution From the Jordanian Pilot - Wilāyat Ninawā (2015), $\mathrm{http} / /$ jihadology.net/2015/02/07/new-video-message-from-the-islamic-state-joy-of-the-muslims-with-the-retribution-from-the-jordanian-pilot-wilayat-ninawa/ (12.04.2016).

Klein G., Kozera C. (2015a), Kurdowie nie chca umierać za Mosul, http://publica.pl/teksty/kurdowie-nie-chca-umierac-za-mosul-50083.html (12.04.2016).

Klein G., Kozera C. (2015b), Organizacja ,, Państwo Islamskie ”, „Zeszyt Problemowy TWO”, nr 3 (78).

Melhem H. (2015), Keeping Up With the Caliphate, „Foreign Affairs”, Vol. 94, No. 6.

New ISIS video showing battle (2014), http://www.liveleak.com/view?i=a7f_1406610219 (12.04.2016).

No Respite (2015), http://www.liveleak.com/view?i=fe3_1448409611 (12.04.2016).

Otlowski T. (2016), Państwo Islamskie, „Bezpieczeństwo i obronność”, nr 1.

Państwo i terytorium w prawie międzynarodowym, (red.) J. Menkes, E. Cała-Wacinkiewicz, Warszawa.

Stability of the Muslims Despite the Bombings of the Crusaders - Wilāyat Ninawā (2016), http://jihadology.net/2016/01/31/new-video-message-from-the-islamic-state-stability-of-the-muslimsdespite-the-bombings-of-the-crusaders-wilayat-ninawa/ (12.04.2016).

Views of the Muslims on the Burning of the Jordanian Pilot - Wilayat Homs (2015), http://jihadology.net/2015/02/16/new-video-message-from-the-islamic-state-views-of-the-muslims-on-theburning-of-the-jordanian-pilot-wilayat- $\% \mathrm{E} 1 \% \mathrm{~B} 8 \% \mathrm{~A} 5 \mathrm{om} \% \mathrm{E} 1 \% \mathrm{~B} 9 \% \mathrm{~A} 3 /(12.04 .2016)$.

Walt S. M. (2015), ISIS as Revolutionary State, „Foreign Affairs”, Vol. 94, No. 6.

Weiss M., Hassan H. (2015), ISIS. Wewnatrz armii terroru, Warszawa.

Winter C. (2015), The Virtual "Caliphate”: Understanding Islamic State's Propaganda Strategy, http://stratcomcoe.org/ (12.04.2016).

Zgryziewicz R. (2015), Daesh Information Campaign and its influence, http://stratcomcoe.org/ (12.04.2016)

\section{STRESZCZENIE}

Celem artykułu było pokazanie różnorodności propagandy Daesh. Składają się na nią treści polityczne, religijne i społeczne. Mają one jedno zadanie - przekonać świat, że nowopowstały 'kalifat' jest faktem: posiada zdolność do obrony swojego terytorium, niezależnie od tego, jak wielkie są wysiłki „krzyżowców”, ponadto stanowi sprawnie działające państwo, będące wymarzonym domem dla sunnitów. Brutalność, będąca tym elementem, z którym propaganda Daesh przede wszystkim się kojarzy, pojawia się niezwykle często. Pełni przy tym określoną rolę - ma odstraszać przeciwników. Temu m.in. służą pokazywane 'polowania' na irackich żołnierzy oraz 
masowe egzekucje. Ta brutalność, w połączeniu z miłosierdziem, zaspokajaniem potrzeb sprawiedliwości i przynależności, do tego nowoczesny sposób montażu i wzbogacania treści, czynią z propagandy Daesh sprawne narzędzie, służące budowaniu i utrzymaniu 'kalifatu'.

Slowa kluczowe: Daesh, propaganda, ISIS, 'Państwo Islamskie'

\title{
DAESH PROPAGANDA
}

\begin{abstract}
The aim of the article was to show the diversity of Daesh propaganda. It consists of the of political, religious and social narratives. They have one task - to convince the world that the newly created 'caliphate' is a fact: it has the ability to defend its territory, no matter of how great is the efforts of 'crusaders', moreover, is an efficient state, which is an ideal home for Sunnis. Brutality is the element with which the propaganda Daesh primarily connotations, appears very frequently. It has specific role - to deter opponents. This reason why so often presents „hunting” on Iraqi soldiers, and mass executions. This brutality, in connection with mercy, meeting the needs of justice and belonging, makes propagandas an efficient tool for building 'caliphate'.
\end{abstract}

Key words: Daesh, propaganda, ISIS, 'Islamic State' 